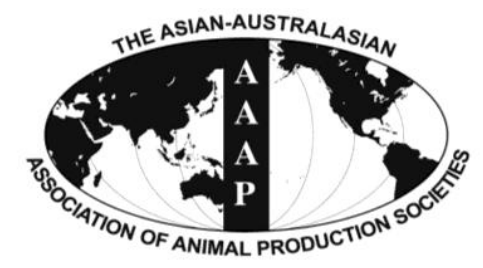

Asian-Aust. J. Anim. Sci.

Vol. 25, No. 5 : 725 - 732

May 2012

www.ajas.info

http://dx.doi.org/10.5713/ajas.2011.11280

\title{
Effects of Hydrated Potato Starch on the Quality of Low-fat Ttoekgalbi (Korean Traditional Patty) Packaged in Modified Atmosphere Conditions during Storage
}

\author{
Muhlisin, S. M. Kang ${ }^{1}$, W. H. Choi, K. T. Lee ${ }^{2}$, S. H. Cheong ${ }^{3}$ and S. K. Lee* \\ Department of Animal Products and Food Science, Kangwon National University, Chuncheon 200-701, Korea
}

\begin{abstract}
This study was carried out to investigate the effects of hydrated potato starch on the quality of low-fat ttoekgalbi (Korean traditional patty) packaged in modified atmosphere conditions during storage. The ttoekgalbi was prepared from 53.2\% lean beef, $13.9 \%$ lean pork, $9.3 \%$ pork fat, and $23.6 \%$ other ingredients. Two low-fat ttoekgalbi treatments were prepared by substituting pork fat with hydrated potato starch; either by $50 \%$ fat replacement (50\% FR) or $100 \%$ fat replacement (100\% FR). Both 50\% and $100 \%$ FR increased the moisture, crude protein, and decreased fat content, cooking loss, and hardness. For MAP studies, $200 \mathrm{~g}$ of ttoekgalbi were placed on the tray and filled with gas composed of $70 \% \mathrm{O}_{2}: 30 \% \mathrm{CO}_{2}\left(70 \% \mathrm{O}_{2}-\mathrm{MAP}\right)$ and $30 \% \mathrm{CO}_{2}: 70 \% \mathrm{~N}_{2}(70 \% \mathrm{~N}$ - $\mathrm{MAP}$ ), and were stored at $5^{\circ} \mathrm{C}$ for $12 \mathrm{~d}$. During the storage time, both $50 \%$ and $100 \%$ FR showed higher protein deterioration, while no differences were found in CIE a*, CIE L*, lipid oxidation, and bacterial counts in comparison to control. The ttoekgalbi with 70\% $\mathrm{O}_{2}-\mathrm{MAP}$ was more red, lighter in color, and showed higher TBARS values compared with $70 \% \mathrm{~N}_{2}$-MAP. The meat with $70 \% \mathrm{~N}_{2}$-MAP showed lower aerobic bacterial counts in control than those with 70\% $\mathrm{O}_{2}$-MAP. The lower anaerobic bacterial counts were observed only in 50\% FR and $100 \%$ FR packed with $70 \% \mathrm{~N}_{2}$-MAP in comparison with $70 \% \mathrm{O}_{2}$-MAP. In conclusion, the fat replacement with hydrated potato starch showed no negative effects on the quality of low fat ttoekgalbi during storage and $70 \% \mathrm{~N}_{2}$-MAP was better than $70 \% \mathrm{O}_{2}$-MAP for low-fat ttoekgalbi packaging. (Key Words: Low-fat Ttoekgalbi (Korean Traditional Patty), Hydrated Potato Starch, Modified Atmosphere Packaging (MAP))
\end{abstract}

\section{INTRODUCTION}

Ttoekgalbi is a Korean traditional patty, generally formulated with lean beef, lean pork and pork back fat as main ingredients. The use of pork back fat as the main ingredient increases its fat contents. It is well known that the high fat intake is associated with increased risk of some diseases like obesity, cancer, high blood cholesterol, and coronary heart diseases (Khalil, 2000). As the interest to healthy food increased, consumer demands for low-fat meat products also increased.

The major problem in acceptability of low-fat processed meat products is decline in palatability with fat reduction

\footnotetext{
* Corresponding Author: Sung Ki Lee. Tel: +82-33-250-8646, Fax: +82-33-251-7719, E-mail: skilee@kangwon.ac.kr

1 National Institute of Animal Science, Rural Development Administration, Suwon 441-706, Korea.

${ }^{2}$ Department of Food Processing and Distribution, GangneungWonju National University, Gangneung 210-702, Korea.

${ }^{3}$ Geo Food Tech Institute, Seongnam 463-741, Korea.

Submitted Aug. 15, 2011; Accepted Dec. 29, 2011; Revised Feb. 2, 2012
}

(Mansour and Khalil, 1997). Water-binding capacity is a critical issue in low-fat meat production (Khalil, 2000), hence it is important to find ingredient that can increase water-holding capacity in low-fat products. It is well known that water-holding capacity is related to cooking loss, and cooking loss itself is an important quality parameter of meat products. Starch is known to have water-binding property and might be used as a fat replacer in meat products (Kim and Lee, 1987; Prabhu and Sebranek, 1997). Starches are glucose polymers derived from corn, potatoes, rice, two polymeric forms, amylase and amylopectin which create three-dimensional gel entrapping water are formed upon hydration (Keeton, 1994). Therefore, incorporation of starch may be beneficial in low-fat, high-added-water processed meat.

Packaging methods are important aspects to maintain the quality of meat products during storage. Modified atmosphere packaging (MAP) has been used by meat industry to extend the shelf-life as well as to keep the quality characteristics of meat products. The main gases used in MAP includes oxygen $\left(\mathrm{O}_{2}\right)$, carbon dioxide $\left(\mathrm{CO}_{2}\right)$ 
and nitrogen $\left(\mathrm{N}_{2}\right)$, and MAP is commonly divided into low oxygen and high oxygen MAP based on the oxygen content. High $\mathrm{O}_{2}$ MAP preserves the bright red color of meat and increases shelf-life by suppressing the anaerobic microbial growth. High $\mathrm{O}_{2}$ MAP may contain $25-90 \% \mathrm{O}_{2}$ and 15 to $80 \% \mathrm{CO}_{2}$ (Blakistone, 1999). Low oxygen MAP may contain less than $20 \%$ of $\mathrm{O}_{2}$ and the rest is composed of $\mathrm{CO}_{2}$ and $\mathrm{N}_{2}$. Carbon dioxide is well known as an antibacterial gas in MAP, while $\mathrm{N}_{2}$ is gas filler. Smith et al. (1990) demonstrated that 20 to $60 \% \mathrm{CO}_{2}$ in MAP retarded aerobic spoilage effectively. Low $\mathrm{CO}_{2}$ concentration (20\%) was better than high concentration $(60 \%)$ in preservation of color and odor of fresh sausages (Martinez et al., 2005). Nitrogen gas is commonly use at $100 \%$ in MAP for cooked and cured meat products (Sebranek and Houser, 2006).

With the increasing concern to high fat intake, it is necessary to develop low-fat meat products as the suitable packaging methods for such products. Moreover, there is little information in the development of low-fat ttoekgalbi using hydrated potato starch as fat replacer as well as the usage of MAP as packaging method. The objective of this study was to evaluate the effect of hydrated potato starch on the quality of low-fat ttoekgalbi packaged in modified atmosphere conditions during storage.

\section{MATERIALS AND METHODS}

\section{Sample preparation}

Ttoekgalbi was prepared using the ingredients presented in Table 1. The lean pork and lean beef (obtained from local market) were chopped separately through a 3-mm plate using a grinder (DFG 450, Daehan Food Machine Co. Ltd., Korea). The chopped lean pork and lean beef were mixed well with other ingredients using a mixer (RM-20, Mainca, Spain). The low-fat ttoekgalbi was prepared by replacing the pork back fat with hydrated potato starch at 50\% $(50 \%$ FR) and $100 \%(100 \%$ FR). The potato starch was hydrated with water at starch:water $=2: 1.5$. For packaging studies, $200 \mathrm{~g}$ of ttoekgalbi were placed on barrier foam tray (maximum $\mathrm{O}_{2}$ transmission rate $=0.1 \mathrm{cc} / \mathrm{cm}^{2}$ at $23^{\circ} \mathrm{C}, 0 \%$ $\mathrm{RH}$; maximum moisture vapor transmission rate $=2.0 \mathrm{~g} / 24$ $\mathrm{h}-254 \mathrm{~cm}^{2}$ at $38^{\circ} \mathrm{C}, 100 \% \mathrm{RH}$, Cryovac sealed air corp., USA). The trays were sealed with $\mathrm{O}_{2}$ barrier film (maximum $\mathrm{O}_{2}$ transmission rate $=0.10 \mathrm{~g} / 24 \mathrm{~h}-254 \mathrm{~m}^{2}$ at 4 ,
Table 1. Ingredients of ttoekgalbi and low-fat ttoekgalbi formulated with potato starch

\begin{tabular}{|c|c|c|c|}
\hline \multirow{2}{*}{ Ingredient $(\%)$} & \multirow{2}{*}{ Control } & \multicolumn{2}{|c|}{ Fat replacement } \\
\hline & & $50 \%$ & $100 \%$ \\
\hline Lean of pork & 13.90 & 13.90 & 13.90 \\
\hline Lean of beef & 53.20 & 53.20 & 53.20 \\
\hline Mixed spices & 17.80 & 17.80 & 17.80 \\
\hline Salt & 0.30 & 0.30 & 0.30 \\
\hline Phosphates & 0.20 & 0.20 & 0.20 \\
\hline Organic acid salts ${ }^{1}$ & 0.40 & 0.40 & 0.40 \\
\hline Hardtact powder & 3.90 & 3.90 & 3.90 \\
\hline Corn syrup & 1.00 & 1.00 & 1.00 \\
\hline Pork fat & 9.30 & 4.65 & 0.00 \\
\hline Hydrated potato $\operatorname{starch}^{2}$ & 0.00 & 4.65 & 9.30 \\
\hline Total & 100.00 & 100.00 & 100.00 \\
\hline
\end{tabular}

${ }^{1}$ Sodium acetate:calcium lactate $=1: 1 .{ }^{2}$ Potato starch: water $=2: 1.5$.

$4^{\circ} \mathrm{C}, 100 \% \mathrm{RH}$; Lid 1050, Cryovac sealed air corp., USA). The trays were filled with modified atmosphere with $70 \%$ $\mathrm{O}_{2}: 30 \% \mathrm{CO}_{2}\left(70 \% \mathrm{O}_{2}-\mathrm{MAP}\right)$ or $30 \% \mathrm{CO}_{2}: 70 \% \mathrm{~N}_{2}(70 \%$ $\mathrm{N}_{2}$-MAP) using modified atmosphere packaging machine (Hypervac, Korea) and the gas mixture MAP Mix $9001 \mathrm{ME}$ (PBI Dansensor, Denmark). $\mathrm{O}_{2}, \mathrm{CO}_{2}, \mathrm{~N}_{2}$ gases were obtained from Baeklyung Specialty Gas Co., Korea, with purity $99.9 \%$. The details of the experimental design are presented in Table 2.

The ttoekgalbi packs were stored in a refrigerator at $5^{\circ} \mathrm{C}$ for $12 \mathrm{~d}$. Proximate analysis, sensory evaluation and physical characteristics analysis were performed to investigate the quality of tttoekgalbi at $0,3,6$, and $12 \mathrm{~d}$ storage. The packs were opened in order to evaluate the storage quality of ttoekgalbi.

\section{Proximate analysis}

The proximate analysis including moisture, crude protein, crude fat and ash was performed by the Association of Official Analytical Chemists (AOAC) methods (1995).

\section{Sensory evaluation}

Panel consisting of 6 trained faculty members and students evaluated the color of raw ttoekgalbi, and the color, flavor, texture and taste of cooked ttoekgalbi. The visual color evaluation was conducted directly from the trays after

Table 2. Experimental design of low-fat ttoekgalbi formulated with hydrated potato starch and packaged in modified atmosphere condition

\begin{tabular}{lcc}
\hline \multirow{2}{*}{ Meat treatment } & \multicolumn{2}{c}{ Gas composition $\left(\mathrm{O}_{2}: \mathrm{CO}_{2}: \mathrm{N}_{2}\right)$} \\
\cline { 2 - 3 } & $70 \% \mathrm{O}_{2}: 30 \% \mathrm{CO}_{2}: 0 \% \mathrm{~N}_{2}\left(70 \% \mathrm{O}_{2}-\mathrm{MAP}\right)$ & $0 \% \mathrm{O}_{2}: 30 \% \mathrm{CO}_{2}: 70 \% \mathrm{~N}_{2}\left(70 \% \mathrm{~N}_{2}-\mathrm{MAP}\right)$ \\
\hline Control $^{1}$ & $\mathrm{Cont}+70 \% \mathrm{O}_{2}$-MAP & $\mathrm{Cont}_{+}+70 \% \mathrm{~N}_{2}-\mathrm{MAP}$ \\
$50 \%$ fat replacement $(\mathrm{FR})^{2}$ & $50 \% \mathrm{FR}+70 \% \mathrm{O}_{2}-\mathrm{MAP}$ & $50 \% \mathrm{FR}+70 \% \mathrm{~N}_{2}-\mathrm{MAP}$ \\
$100 \%$ Fat replacement $(\mathrm{FR})^{3}$ & $100 \% \mathrm{FR}+70 \% \mathrm{O}_{2}-\mathrm{MAP}$ & $100 \% \mathrm{FR}+70 \% \mathrm{~N}_{2}-\mathrm{MAP}$ \\
\hline
\end{tabular}

${ }^{1}$ Pork fat $=9.3 \%$, Hydrated potato starch $=0 \%{ }^{2}$ Pork fat $=4.65 \%$, Hydrated potato starch $=4.65 \% .{ }^{3}$ Pork fat $=0 \%$, Hydrated potato starch $=9.3 \%$. 
gas composition analysis. The panelist scored all parameters with scores ranging from 1 to $9(9=$ extremely like, $7=$ like, $5=$ moderate like, $3=$ dislike, and $1=$ extremely dislike).

\section{Thiobarbituric acid reactive substances (TBARS) analysis}

The TBARS value was measured according to Sinnhuber and Yu (1977). Briefly, $0.5 \mathrm{~g}$ sample was mixed with 3 drops of antioxidant solution (3\% BHA-54\% propylene glycol-3\% BHT-40\% Tween20), $3 \mathrm{ml}$ of TBA solution (1\% 4,6-Dihydroxy-2-mercaptopyrimidine), and 17 $\mathrm{ml}$ of $25 \%$ Trichloroacetic acid. The mixture was heated at $100^{\circ} \mathrm{C}$ for $30 \mathrm{~min}$, and centrifuged at 3,500 rpm for $30 \mathrm{~min}$. An absorbance of supernatant was measured at $532 \mathrm{~nm}$ using a spectrophotometer (UV-mini-1240, Shimadzu, Japan). The results were calculated as $\mathrm{mg}$ malonaldehyde (MA) per kg sample.

\section{Color measurement}

Color changes on the surface of ttoekgalbis were monitored by measuring the CIE lightness ( $\left.\mathrm{L}^{*}\right)$ and redness (a*) using a color difference meter (CR-400, Konica Minolta Sensing Inc., Japan) and an illuminant C. The color instrument was calibrated using a white plate (Illuminant $\mathrm{C}$ : $\mathrm{Y}=93.6, \mathrm{x}=0.3134$, and $\mathrm{y}=0.3194)$. Color measurements were directly performed on the surface of sample immediately after the packs were opened. The color of ground beef patties surface was measured 30 times in each pack at different locations.

\section{Cooking loss and hardness measurement}

Hardness analysis was carried out using a texture analyzer (TA-XT2 $i$ version 6.06, Stable Micro Systems Ltd., $\mathrm{UK})$. Thirty two grams of ttoekgalbis were placed in petridish with $60 \mathrm{~mm}$ dia. $\times 15 \mathrm{~mm}$ depth (SPL Life Science, Korea). The ttoekgalbi was placed in the zipper bag and boiled at $75^{\circ} \mathrm{C}$ for $45 \mathrm{~min}$. The cooked ttoekgalbi was then cooled at $4^{\circ} \mathrm{C}$ for $12 \mathrm{~h}$. The water on the cooked toekgalbi was removed using Whatman paper No. 1. The weight of cooked ttoekgalbi was measured and the cooking losses were determined. For hardness measurement, the samples were sliced in squares $(1 \mathrm{~cm} \times 1 \mathrm{~cm})$. The hardness was measured using a 5-mm cylindrical probe. The measurements were performed by three sample replications for every treatment and 10 hardness measurements were performed for every sample. Hardness is expressed as kgf.

\section{pH determination}

For $\mathrm{pH}$ determination, $10 \mathrm{~g}$ sample was added with 100 $\mathrm{ml}$ distilled water and then homogenized at 10,000 rpm for $60 \mathrm{~s}$ using a homogenizer (PH91, SMT Co. Ltd., Japan). The $\mathrm{pH}$ of the homogenized sample was measured using a $\mathrm{pH}$ meter (SevenEasy $\mathrm{pH}$, Mettler-Toledo $\mathrm{GmbH}$,
Switzerland). The measurements were performed by three sample replications for every treatment and $\mathrm{pH}$ determinations were performed in duplicates for every sample.

\section{Volatile basic nitrogen (VBN) value analysis}

The analysis of VBN was measured using the method of Kohsaka (1975). Five gram sample was homogenized with $30 \mathrm{ml}$ of $5 \%(\mathrm{w} / \mathrm{v})$ TCA using a homogenizer (Ultra-Turrax T25 basic, Ika Werke GmbH and Co., Germany) at 13,500 rpm for $2 \mathrm{~min}$. The homogenate was made up to $50 \mathrm{ml}$ of final volume with $5 \%(\mathrm{w} / \mathrm{v})$ TCA and filtered through a Whatman No. 1 filter paper. One $\mathrm{mL}$ of the filtrate and $1 \mathrm{ml}$ of borate buffer were placed in outer and inner of Conway dish, respectively, and then incubated at $37^{\circ} \mathrm{C}$ for $100 \mathrm{~min}$. Finally, the inner solution was titrated with $0.01 \mathrm{~N} \mathrm{HCl}$.

\section{Microbial analysis}

Ten grams of sample was placed in an autoclaved bag (Nasco Co., Ltd., USA) and added with $90 \mathrm{ml}$ of $0.1 \%$ (w/v) peptone solution. Each sample was homogenized using a Stomacher (Lab Blender 400, Seward Laboratory, UK) at medium speed for $2 \mathrm{~min}$. Serial 10-fold dilutions were performed by mixing $1 \mathrm{ml}$ of solution with $9 \mathrm{ml}$ of $0.1 \%$ (w/v) peptone solution. Plate count agar (Difco, USA) was used for aerobic and anaerobic bacterial counts. Agar plates were prepared according to the manufacturer's instruction. Samples were incubated for $48 \mathrm{~h}$ at $35^{\circ} \mathrm{C}$. Microbial populations were counted in 30 to 300 colonies and expressed as log CFU per gram of sample.

\section{Statistical analysis}

All data were analyzed using SPSS 14.0 for Windows Evaluation Version (2005). The data was analyzed by one way analysis of variance, with treatments (fat replacement and packaging method) as variable. Means of data in every day of storage were compared using Duncan's multiple range tests with examination for significant differences $(\mathrm{p}<0.05)$.

\section{RESULTS AND DISCUSSION}

\section{Quality properties of low-fat ttoekgalbi}

The quality properties of low-fat ttoekgalbi that includes proximate composition, cooking loss, sensory evaluation and texture (hardness) are presented in Table 3. The replacement of pork fat using potato at $50 \%$ and $100 \%$ significantly increased $(\mathrm{p}<0.05)$ the moisture contents of ttoekgalbi from $62.47 \%$ to $66.27 \%$ and $68.89 \%$, respectively. This result is in agreement with Choi et al. (2010) who reported higher moisture contents in reducedfat meat using rice brand fiber. Previous research reported that the fat replacement using pork rind increased the 
Table 3. Characteristics and quality properties of low fat ttoekgalbi formulated with hydrated potato starch

\begin{tabular}{lrrr}
\hline \multirow{2}{*}{ Parameter } & \multicolumn{3}{c}{ Fat replacement } \\
\cline { 2 - 4 } & $0 \%$ (control) & \multicolumn{1}{c}{$50 \%$ FR } & \multicolumn{1}{c}{$100 \%$ FR } \\
\hline Moisture & $62.47 \pm 1.11^{\mathrm{c}}$ & $66.27 \pm 1.15^{\mathrm{b}}$ & $68.89 \pm 0.55^{\mathrm{a}}$ \\
Crude ash & $1.32 \pm 0.06^{\mathrm{a}}$ & $1.33 \pm 0.10^{\mathrm{a}}$ & $1.36 \pm 0.01^{\mathrm{a}}$ \\
Crude protein & $14.90 \pm 0.32^{\mathrm{c}}$ & $15.77 \pm 0.32^{\mathrm{b}}$ & $16.84 \pm 0.47^{\mathrm{a}}$ \\
Crude fat & $19.40 \pm 1.69^{\mathrm{a}}$ & $15.45 \pm 0.86^{\mathrm{b}}$ & $12.79 \pm 0.66^{\mathrm{c}}$ \\
Cooking loss (\%) & $7.44 \pm 0.90^{\mathrm{a}}$ & $2.77 \pm 2.81^{\mathrm{b}}$ & $0.98 \pm 0.80^{\mathrm{c}}$ \\
Sensory evaluation & & & \\
$\quad$ Raw-color & $7.33 \pm 1.17^{\mathrm{a}}$ & $8.40 \pm 0.83^{\mathrm{a}}$ & $8.53 \pm 0.83^{\mathrm{a}}$ \\
$\quad$ & & \\
$\quad$ Cooked & & & \\
$\quad$ Color & $7.88 \pm 0.88^{\mathrm{a}}$ & $7.56 \pm 0.63^{\mathrm{a}}$ & $7.50 \pm 0.73^{\mathrm{a}}$ \\
$\quad$ Flavor & $8.25 \pm 0.86^{\mathrm{a}}$ & $8.00 \pm 0.82^{\mathrm{a}}$ & $8.13 \pm 1.14^{\mathrm{a}}$ \\
$\quad$ Texture & $8.25 \pm 0.77^{\mathrm{a}}$ & $7.81 \pm 0.83^{\mathrm{a}}$ & $7.31 \pm 1.40^{\mathrm{a}}$ \\
$\quad$ Taste & $8.19 \pm 0.75^{\mathrm{a}}$ & $7.94 \pm 0.77^{\mathrm{a}}$ & $7.69 \pm 1.20^{\mathrm{a}}$ \\
Hardness (kgf) & $15.80 \pm 1.71^{\mathrm{a}}$ & $14.97 \pm 1.76^{\mathrm{a}}$ & $14.97 \pm 0.62^{\mathrm{a}}$ \\
\hline a-c Values (Means \pm SD) & with different superscripts in the same row differ \\
significantly (p<0.05), n $=5$. & &
\end{tabular}

moisture contents of sausage (Abiola and Adegbaju, 2001). The fat replacement using corn starch also increased the moisture contents of beef patties (Khalil, 2000). Higher moisture contents in low-fat ttoekgalbi may be related to the moisture binding ability of potato starch. Berry and Wergin (1993) reported high moisture binding capacity of potato starch and Troutt et al. (1992) reported moisture binding capacity of dietary fibers and starches.

The quality properties of low-fat ttoekgalbi that includes proximate composition, cooking loss, sensory evaluation and texture (hardness) are presented in Table 3. The replacement of pork fat using potato at $50 \%$ and $100 \%$ significantly increased $(\mathrm{p}<0.05)$ the moisture contents of ttoekgalbi from $62.47 \%$ to $66.27 \%$ and $68.89 \%$, respectively. This result is in agreement with Choi et al. (2010) who reported higher moisture contents in reducedfat meat using rice brand fiber. Previous research reported that the fat replacement using pork rind increased the moisture contents of sausage (Abiola and Adegbaju, 2001). The fat replacement using corn starch also increased the moisture contents of beef patties (Khalil, 2000). Higher moisture contents in low-fat ttoekgalbi may be related to the moisture binding ability of potato starch. Berry and Wergin (1993) reported high moisture binding capacity of potato starch and Troutt et al. (1992) reported moisture binding capacity of dietary fibers and starches.

The replacement of pork fat with potato starch at $50 \%$ and $100 \%$ significantly increased $(\mathrm{p}<0.05)$ crude protein and decreased $(\mathrm{p}<0.05)$ crude fat content in ttoekgalbi. Protein content in the ttoekgalbi increased from $14.90 \%$ to $15.77 \%$ and $16.84 \%$, while fat content decreased from $19.40 \%$ to $15.45 \%$ and $12.79 \%$ respectively. The results showed that the potato starch is effective in lowering fat contents in ttoekgalbi. Abiola and Adegbaju (2001) reported decrease in fat content and increase in crude protein by replacing pork back fat with increasing level of pork rind in low-fat sausage. In addition, Osburn and Keeton (1994) manufactured low-fat pork sausages with konjac flour gel and concluded that all treated sausages were different than control, exhibiting higher percentage for moisture, protein and lower percentage of fat.

The cooking loss in low-fat ttoekgalbi was lower $(\mathrm{p}<0.05)$ compared to control. Our result is in agreement with Park et al. (2005) and Choi et al. (2010), but different with Hughes et al. (1998). The lower cooking loss in lowfat ttoekgalbi may be attributed to higher protein and lower fat contents of low-fat ttoekgalbi. Cooking loss is affected by the amount of fat contents in meat products (Hong et al., 2004) and fat type (Choi et al., 2009) because protein has an ability to trap moisture and reduce moisture loss (Abiola and Adegbaju, 2001).

There were no negative effects on sensory evaluation by the fat replacement with hydrated potato starch for low fat ttoekgalbi. The scores of taste, flavor, texture, and color of cooked low-fat ttoekgalbi, and color of uncooked low-fat ttoekgalbi were similar to those of control ttoekgalbi. Also, no differences were noticed in hardness of cooked low-fat ttoekgalbi. These are similar results in which no difference was found in flavor score of low fat ground beef formulated with potato starch (Khalil, 2000), and starch (Berry and Wergin, 1993). However, Hughes et al. (1997) and Abiola and Adegbaju (2001) reported decrease in sensory properties of low-fat sausage formulated with pork rind. The fat replacement in low-fat ground beef decreased the hardness and that might be due to higher moisture content of the low-fat patties (Khalil, 2000).

\section{Quality changes of ttoekgalbi during storage}

The $\mathrm{pH}$ value: The $\mathrm{pH}$ values of low-fat ttoekgalbi formulated with hydrated potato starch and treated with MAP are presented in Table 4 . On $0 \mathrm{~d}$ of storage, the $\mathrm{pH}$ of $50 \%$ FR and $100 \%$ FR was higher than control. Choi et al. (2010) reported the higher $\mathrm{pH}$ value of low-fat meat emulsion system formulated with vegetable oil and rice brand fiber. On $3 \mathrm{~d}$ and $6 \mathrm{~d}$, the replacement of pork fat with hydrated potato starch decreased $(\mathrm{p}<0.05) \mathrm{pH}$ value compared to control, but the different percentage of replacement $(50 \%$ and $100 \%)$ did not affect the $\mathrm{pH}$ value. The lower $\mathrm{pH}$ value might be related with the lower VBN observed in low-fat ttoekgalbi (Table 4). Ruiz-Capillas and Moral (2001) reported the positive correlation between $\mathrm{pH}$ and VBN value of hake stored in ice. At the end of storage, the $\mathrm{pH}$ value decreased suddenly. The possible reason of the decreased of $\mathrm{pH}$ might be related to the increased of bacterial counts (Table 7). Nassos et al. (1983) observed the 
Table 4. Effect of hydrated potato starch on $\mathrm{pH}$ and VBN value (\% mg sample) of low-fat ttoekgalbi packaged in modified atmosphere conditions during storage

\begin{tabular}{|c|c|c|c|c|c|c|c|}
\hline & \multirow{3}{*}{$\begin{array}{c}\text { Storage } \\
\text { day }\end{array}$} & \multicolumn{6}{|c|}{ Treatments } \\
\hline & & \multicolumn{2}{|c|}{$0 \% \mathrm{FR}$} & \multicolumn{2}{|c|}{$50 \% \mathrm{FR}$} & \multicolumn{2}{|c|}{$100 \% \mathrm{FR}$} \\
\hline & & $70 \% \mathrm{O}_{2}$-MAP & $70 \% \mathrm{~N}_{2}$-MAP & $70 \% \mathrm{O}_{2}$-MAP & $70 \% \mathrm{~N}_{2}-\mathrm{MAP}$ & $70 \% \mathrm{O}_{2}$-MAP & $70 \% \mathrm{~N}_{2}-\mathrm{MAP}$ \\
\hline \multirow[t]{5}{*}{$\mathrm{pH}$} & 0 & $6.20 \pm 0.02^{\mathrm{bC}}$ & $6.20 \pm 0.02^{\mathrm{bC}}$ & $6.24 \pm 0.01^{\mathrm{aC}}$ & $6.24 \pm 0.01^{\mathrm{aA}}$ & $6.25 \pm 0.01^{\mathrm{aA}}$ & $6.25 \pm 0.01^{\mathrm{aB}}$ \\
\hline & 3 & $6.38 \pm 0.03^{\mathrm{aB}}$ & $6.37 \pm 0.02^{\mathrm{aB}}$ & $6.29 \pm 0.01^{\mathrm{cBC}}$ & $6.32 \pm 0.02^{\mathrm{bA}}$ & $6.29 \pm 0.02^{\mathrm{cA}}$ & $6.29 \pm 0.01^{\mathrm{cAB}}$ \\
\hline & 6 & $6.54 \pm 0.04^{\mathrm{aA}}$ & $6.46 \pm 0.01^{\mathrm{bA}}$ & $6.38 \pm 0.01^{\mathrm{cA}}$ & $6.36 \pm 0.01^{\mathrm{cA}}$ & $6.39 \pm 0.01^{\mathrm{cA}}$ & $6.37 \pm 0.01^{\mathrm{cA}}$ \\
\hline & 9 & $6.58 \pm 0.09^{\mathrm{aA}}$ & $6.15 \pm 0.10^{\mathrm{cdC}}$ & $6.30 \pm 0.07^{\mathrm{bB}}$ & $6.08 \pm 0.05^{\mathrm{dA}}$ & $6.22 \pm 0.12^{\mathrm{bcA}}$ & $6.31 \pm 0.06^{\mathrm{bAB}}$ \\
\hline & 12 & $4.90 \pm 0.07^{\mathrm{aD}}$ & $4.70 \pm 0.15^{\mathrm{aD}}$ & $4.77 \pm 0.02^{\mathrm{aD}}$ & $4.68 \pm 0.02^{\mathrm{aB}}$ & $4.74 \pm 0.07^{\mathrm{aB}}$ & $4.72 \pm 0.11^{\mathrm{aC}}$ \\
\hline \multirow[t]{5}{*}{ VBN } & 0 & $15.45 \pm 2.37^{\mathrm{aC}}$ & $15.45 \pm 2.37^{\mathrm{aC}}$ & $12.03 \pm 2.38^{\mathrm{bC}}$ & $12.02 \pm 2.38^{\mathrm{bC}}$ & $10.28 \pm 1.10^{\mathrm{bD}}$ & $10.28 \pm 1.10^{\mathrm{bD}}$ \\
\hline & 3 & $17.75 \pm 2.13^{\mathrm{aBC}}$ & $17.56 \pm 1.75^{\mathrm{aB}}$ & $13.54 \pm 2.50^{\mathrm{bcC}}$ & $14.96 \pm 2.51^{\mathrm{bB}}$ & $12.81 \pm 1.32^{\mathrm{bcC}}$ & $11.64 \pm 0.88^{\mathrm{cCD}}$ \\
\hline & 6 & $20.22 \pm 1.27^{\mathrm{aB}}$ & $17.92 \pm 1.41^{\mathrm{bB}}$ & $17.22 \pm 1.58^{\mathrm{bB}}$ & $17.11 \pm 1.96^{\mathrm{bAB}}$ & $13.26 \pm 1.34^{\mathrm{cC}}$ & $12.26 \pm 2.00^{\mathrm{cC}}$ \\
\hline & 9 & $19.01 \pm 1.40^{\mathrm{aB}}$ & $17.35 \pm 3.71^{\mathrm{aB}}$ & $17.22 \pm 2.44^{\mathrm{aB}}$ & $18.55 \pm 0.78^{\mathrm{aA}}$ & $17.15 \pm 2.03^{\mathrm{aB}}$ & $16.44 \pm 1.26^{\mathrm{aB}}$ \\
\hline & 12 & $22.15 \pm 3.00^{\mathrm{aA}}$ & $20.74 \pm 1.24^{\mathrm{aA}}$ & $20.71 \pm 2.84^{\mathrm{aA}}$ & $19.43 \pm 2.08^{\mathrm{aA}}$ & $20.76 \pm 1.80^{\mathrm{aA}}$ & $21.89 \pm 0.67^{\mathrm{aA}}$ \\
\hline
\end{tabular}

${ }^{a-c}$ Values (Means \pm SD) with different superscripts in the same row differ significantly $(\mathrm{p}<0.05)$.

${ }^{\text {A-E }}$ Values (Means $\pm \mathrm{SD}$ ) with different superscripts in the same column differ significantly $(\mathrm{p}<0.05), \mathrm{n}=6$.

increased of $\mathrm{pH}$ value in ground beef because of the increase of bacterial counts, percentage of gram-positive bacteria and the present of lactic acid-producing bacteria. During the storage time, the different gas compositions in MAP showed no effect on $\mathrm{pH}$ value in both control and low-fat ttoekgalbi. This result is similar trend to our earlier study (Muhlisin et al., 2010) that showed no difference in $\mathrm{pH}$ value of ground beef packed with $70 \% \mathrm{O}_{2}$-MAP and $70 \% \mathrm{~N}_{2}-\mathrm{MAP}$, while ground beef added with organic acid and packed with $70 \% \mathrm{O}_{2}$-MAP showed higher $\mathrm{pH}$ values than $70 \% \mathrm{~N}_{2}$-MAP. In addition, Viana et al. (2005) also reported that MAP did not show strong variation in $\mathrm{pH}$ of fresh pork loin.

Volatile basic nitrogen (VBN) value: The protein deterioration (represented by VBN value) of low-fat ttoekgalbi formulated with hydrated potato starch treated with MAP is presented in Table 4. The VBN value of low fat ttoekgalbi was significantly lower $(\mathrm{p}<0.05)$ than control on $0 \mathrm{~d}$ to $6 \mathrm{~d}$ storage. On 3 and $6 \mathrm{~d}$ storage, the VBN value was decreased in number as the increasing of percentage of fat replacement. Protein deterioration is associated with the activity of amino acid decarboxylase of microorganisms (Lin and Lin, 2002). The VBN values increased in all the treatments with the increasing storage time. Arashihar et al. (2004) reported that VBN values increased with the increasing storage time in air packaging, vacuum and MAP of rainbow trout (Oncorynchus mykiss) fillets. MAP did not show any effect on VBN values in all the treatment during the storage time. In control ttoekgalbi, $70 \% \quad \mathrm{~N}_{2}$-MAP resulted in lower VBN value but statistically it was not different ( $\mathrm{p}>0.05)$.

Thiobarbituric acid reactive substance (TBARS) value: The TBARS values in low-fat ttoekgalbi (both in 50\% and $100 \%$ replacement) were lower compared to the control until $3 \mathrm{~d}$ of storage (Table 5). This may be due to the lower fat contents in low fat ttoekgalbi compared to control. The $70 \% \mathrm{O}_{2}$-MAP increased $(\mathrm{p}<0.05)$ TBARS value both in control and low-fat ttoekgalbi during the storage compared to $70 \% \mathrm{~N}_{2}$-MAP. Similarly, Lund et al. (2007) showed that $100 \% \mathrm{~N}_{2}$ MAP significantly lower TBARS value with or without organic acid salts in beef patties. Skibsted et al. (1998) mentioned one of the factors affecting lipid

Table 5. Effect of hydrated potato starch on TBARS value (mg MA/kg sample) of low-fat ttoekgalbi packaged in modified atmosphere conditions during storage

\begin{tabular}{|c|c|c|c|c|c|c|}
\hline \multirow{3}{*}{ Day } & \multicolumn{6}{|c|}{ Treatment } \\
\hline & \multicolumn{2}{|c|}{$0 \% \mathrm{FR}$} & \multicolumn{2}{|c|}{$50 \% \mathrm{FR}$} & \multicolumn{2}{|c|}{$100 \% \mathrm{FR}$} \\
\hline & $70 \% \mathrm{O}_{2}$-MAP & $70 \% \mathrm{~N}_{2}$-MAP & $70 \% \mathrm{O}_{2}$-MAP & $70 \% \mathrm{~N}_{2}$-MAP & $70 \% \mathrm{O}_{2}$-MAP & $70 \% \mathrm{~N}_{2}$-MAP \\
\hline 0 & $0.59 \pm 0.10^{\mathrm{aC}}$ & $0.59 \pm 0.10^{\mathrm{aC}}$ & $0.56 \pm 0.10^{\mathrm{aC}}$ & $0.56 \pm 0.10^{\mathrm{aB}}$ & $0.53 \pm 0.11^{\mathrm{aC}}$ & $0.53 \pm 0.11^{\mathrm{aB}}$ \\
\hline 3 & $0.95 \pm 0.06^{\mathrm{aB}}$ & $0.80 \pm 0.21^{\mathrm{abB}}$ & $0.84 \pm 0.05^{\mathrm{abB}}$ & $0.72 \pm 0.19^{\mathrm{bcA}}$ & $0.64 \pm 0.20^{\mathrm{cC}}$ & $0.62 \pm 0.14^{\mathrm{cB}}$ \\
\hline 6 & $0.96 \pm 0.05^{\mathrm{aB}}$ & $0.82 \pm 0.08^{\mathrm{cB}}$ & $0.93 \pm 0.04^{\mathrm{abB}}$ & $0.82 \pm 0.13^{\mathrm{cA}}$ & $0.96 \pm 0.10^{\mathrm{aA}}$ & $0.87 \pm 0.09^{\mathrm{abcA}}$ \\
\hline 9 & $1.20 \pm 0.22^{\mathrm{aA}}$ & $0.97 \pm 0.05^{\mathrm{bA}}$ & $1.23 \pm 0.16^{\mathrm{aA}}$ & $0.79 \pm 0.18^{\mathrm{dA}}$ & $0.94 \pm 0.11^{\mathrm{bcA}}$ & $0.83 \pm 0.06^{\mathrm{cdA}}$ \\
\hline 12 & $0.99 \pm 0.20^{\mathrm{aB}}$ & $0.66 \pm 0.08^{\mathrm{cdC}}$ & $0.82 \pm 0.19^{\mathrm{bB}}$ & $0.52 \pm 0.10^{\mathrm{dB}}$ & $0.78 \pm 0.17^{\mathrm{bcB}}$ & $0.57 \pm 0.13^{\mathrm{dC}}$ \\
\hline
\end{tabular}

${ }^{a-c}$ Values (Means \pm SD) with different superscripts in the same row differ significantly $(\mathrm{p}<0.05)$.

${ }^{\mathrm{A}-\mathrm{E}}$ Values (Means $\left.\pm \mathrm{SD}\right)$ with different superscripts in the same column differ significantly $(\mathrm{p}<0.05), \mathrm{n}=12$. 
Table 6. Effect of hydrated potato starch on instrumental color value of low-fat ttoekgalbi packaged in modified atmosphere conditions during storage

\begin{tabular}{|c|c|c|c|c|c|c|c|}
\hline \multirow{3}{*}{$\begin{array}{c}\text { Storage } \\
\text { day }\end{array}$} & & \multicolumn{6}{|c|}{ Treatments } \\
\hline & & \multicolumn{2}{|c|}{$0 \%$ FR } & \multicolumn{2}{|c|}{$50 \% \mathrm{FR}$} & \multicolumn{2}{|c|}{$100 \% \mathrm{FR}$} \\
\hline & & $70 \% \mathrm{O}_{2}$-MAP & $70 \% \mathrm{~N}_{2}$-MAP & $70 \% \mathrm{O}_{2}$-MAP & $70 \% \mathrm{~N}_{2}$-MAP & $70 \% \mathrm{O}_{2}$-MAP & $70 \% \mathrm{~N}_{2}$-MAP \\
\hline \multirow[t]{5}{*}{ CIE L*1 } & 0 & $53.17 \pm 1.89^{\mathrm{bB}}$ & $53.17 \pm 1.89^{\mathrm{bA}}$ & $54.39 \pm 2.32^{\mathrm{aA}}$ & $54.39 \pm 2.32^{\mathrm{aA}}$ & $54.28 \pm 2.10^{\mathrm{aAB}}$ & $54.28 \pm 2.01^{\mathrm{aA}}$ \\
\hline & 3 & $53.91 \pm 1.93^{\mathrm{aAB}}$ & $53.41 \pm 2.17^{\mathrm{aA}}$ & $53.42 \pm 2.16^{\mathrm{aB}}$ & $53.58 \pm 2.16^{\mathrm{aA}}$ & $53.60 \pm 2.32^{\mathrm{aB}}$ & $53.35 \pm 2.01^{\mathrm{aA}}$ \\
\hline & 6 & $53.34 \pm 2.91^{\mathrm{bB}}$ & $53.38 \pm 2.39^{\mathrm{bA}}$ & $54.81 \pm 2.64^{\mathrm{aA}}$ & $53.36 \pm 2.25^{\mathrm{aA}}$ & $54.79 \pm 2.11^{\mathrm{a} A \mathrm{~B}}$ & $53.74 \pm 2.09^{\mathrm{aA}}$ \\
\hline & 9 & $54.24 \pm 2.91^{\mathrm{abcA}}$ & $53.99 \pm 2.31^{\mathrm{cdA}}$ & $54.96 \pm 2.35^{\mathrm{aA}}$ & $53.97 \pm 2.59^{\mathrm{cdA}}$ & $54.60 \pm 2.22^{\mathrm{abAB}}$ & $53.44 \pm 2.86^{\mathrm{dA}}$ \\
\hline & 12 & $54.68 \pm 2.89^{\mathrm{aA}}$ & $52.68 \pm 2.48^{\mathrm{bA}}$ & $55.03 \pm 2.52^{\mathrm{aA}}$ & $53.27 \pm 2.06^{\mathrm{bA}}$ & $55.23 \pm 2.49^{\mathrm{aA}}$ & $53.32 \pm 2.27^{\mathrm{bA}}$ \\
\hline \multirow[t]{5}{*}{ CIE $\mathrm{a}^{*^{2}}$} & 0 & $10.57 \pm 0.93^{\mathrm{bA}}$ & $10.57 \pm 0.93^{\mathrm{bC}}$ & $11.66 \pm 1.10^{\mathrm{aA}}$ & $11.66 \pm 1.10^{\mathrm{aA}}$ & $10.37 \pm 1.65^{\mathrm{bA}}$ & $10.37 \pm 1.65^{\mathrm{bB}}$ \\
\hline & 3 & $7.92 \pm 1.02^{\mathrm{dB}}$ & $10.99 \pm 1.54^{\mathrm{aC}}$ & $8.60 \pm 1.44^{\mathrm{cB}}$ & $9.60 \pm 1.17^{\mathrm{bD}}$ & $8.19 \pm 1.38^{\mathrm{dB}}$ & $9.92 \pm 1.14^{\mathrm{bC}}$ \\
\hline & 6 & $6.86 \pm 1.11^{\mathrm{eC}}$ & $11.62 \pm 1.45^{\mathrm{aB}}$ & $7.68 \pm 1.35^{\mathrm{dC}}$ & $10.40 \pm 1.54^{\mathrm{bC}}$ & $7.79 \pm 1.28^{\mathrm{dC}}$ & $9.78 \pm 1.42^{\mathrm{cC}}$ \\
\hline & 9 & $6.95 \pm 1.03^{\mathrm{dC}}$ & $12.50 \pm 1.66^{\mathrm{aA}}$ & $7.28 \pm 1.20^{\mathrm{cdD}}$ & $11.21 \pm 1.56^{\mathrm{bB}}$ & $7.42 \pm 1.10^{\mathrm{cC}}$ & $11.32 \pm 1.26^{\mathrm{bA}}$ \\
\hline & 12 & $4.45 \pm 1.04^{\mathrm{dD}}$ & $10.98 \pm 1.48^{\mathrm{aC}}$ & $3.40 \pm 0.81^{\mathrm{eE}}$ & $9.50 \pm 1.19^{\mathrm{cD}}$ & $3.71 \pm 1.06^{\mathrm{eD}}$ & $10.35 \pm 1.49^{\mathrm{bB}}$ \\
\hline
\end{tabular}

\footnotetext{
${ }^{a-c}$ Values (Means \pm SD) with different superscripts in the same row differ significantly $(\mathrm{p}<0.05)$.

${ }^{\text {A-E }}$ Values (Means \pm SD) with different superscripts in the same column differ significantly $(\mathrm{p}<0.05), \mathrm{n}=90$.

${ }^{1}$ Lightness. ${ }^{2}$ Redness.
}

oxidation is oxygen concentration in packaging. These results are also in agreement with those of Cayuela et al. (2004); John et al. (2005); and McMillin (2008) who showed that high oxygen packaging resulted in higher lipid oxidation, compared with vacuum packaging or low oxygen packaging in meat. These results indicated that lipid oxidation of tteokgalbi could be inhibited by FR with hydrated potato starch and $70 \% \mathrm{~N}_{2}$-MAP.

Instrumental color: Fat replacement with hydrated potato starch resulted in lighter $(\mathrm{p}<0.05)$ toekgalbi compared to control, while different percent of fat replacement $(50 \%$ and $100 \%)$ gave no effect on CIE L* value (Table 6). On $0 \mathrm{~d}$, low-fat ttoekgalbi with $50 \%$ fat replacement showed more red $(\mathrm{p}<0.05)$ color compared to control ttoekgalbi and low-fat ttoekgalbi with $100 \%$ fat replacement, while no difference was found in redness between control and low-fat ttoekgalbi with $100 \%$ fat replacement. Papadima and Bloukas (1999) found that fat level affected the lightness and redness of low-fat traditional Greek sausages, but Garson et al. (2003) noted that no difference were found in CIE L* and CIE a* in lowfat beef patties formulated with carbohydrate-lipid composite. Choi et al. (2010) reported that increasing grape seed oil levels from $0 \%$ to $15 \%$ as fat replacement significantly increased the lightness of uncooked and cooked batters. Hoffman and Mellet (2003) reported that the patties containing fat were all lighter than that with containing the fat replacer (higher CIE L* values) in low-fat

Table 7. Effect of hydrated potato starch on aerobic and anaerobic bacterial counts (Log CFU/g sample) of low-fat ttoekgalbi packaged in modified atmosphere conditions during storage

\begin{tabular}{|c|c|c|c|c|c|c|c|}
\hline \multirow{3}{*}{$\begin{array}{c}\text { Storage } \\
\text { day }\end{array}$} & & \multicolumn{6}{|c|}{ Treatments } \\
\hline & & \multicolumn{2}{|c|}{$0 \% \mathrm{FR}$} & \multicolumn{2}{|c|}{$50 \% \mathrm{FR}$} & \multicolumn{2}{|c|}{$100 \% \mathrm{FR}$} \\
\hline & & $70 \% \mathrm{O}_{2}$-MAP & $70 \% \mathrm{~N}_{2}$-MAP & $70 \% \mathrm{O}_{2}$-MAP & $70 \% \mathrm{~N}_{2}$-MAP & $70 \% \mathrm{O}_{2}$-MAP & $70 \% \mathrm{~N}_{2}$-MAP \\
\hline \multirow[t]{5}{*}{$\mathrm{AE}^{1}$} & 0 & $5.37 \pm 0.06^{\mathrm{aC}}$ & $5.37 \pm 0.06^{\mathrm{aC}}$ & $5.35 \pm 0.12^{\mathrm{aC}}$ & $5.35 \pm 0.12^{\mathrm{aC}}$ & $5.31 \pm 0.15 \mathrm{a}^{\mathrm{aC}}$ & $5.31 \pm 0.15^{\mathrm{aC}}$ \\
\hline & 3 & $5.39 \pm 0.09^{\mathrm{aC}}$ & $5.41 \pm 0.13^{\mathrm{aC}}$ & $5.38 \pm 0.15^{\mathrm{aC}}$ & $5.48 \pm 0.28^{\mathrm{aC}}$ & $5.53 \pm 0.37^{\mathrm{aC}}$ & $5.47 \pm 0.26^{\mathrm{aC}}$ \\
\hline & 6 & $5.38 \pm 0.00^{\mathrm{aC}}$ & $5.47 \pm 0.23^{\mathrm{aC}}$ & $5.43 \pm 0.12^{\mathrm{aC}}$ & $5.33 \pm 0.10^{\mathrm{aC}}$ & $5.59 \pm 0.14^{\mathrm{aC}}$ & $5.64 \pm 0.23^{\mathrm{aC}}$ \\
\hline & 9 & $6.60 \pm 0.31^{\mathrm{abB}}$ & $6.62 \pm 0.11^{\mathrm{abB}}$ & $6.95 \pm 0.49^{\mathrm{aB}}$ & $6.24 \pm 0.34^{\mathrm{bB}}$ & $6.84 \pm 0.27^{\mathrm{aB}}$ & $6.64 \pm 0.39^{\mathrm{abB}}$ \\
\hline & 12 & $8.52 \pm 0.05^{\mathrm{aA}}$ & $8.46 \pm 0.16^{\mathrm{aA}}$ & $8.54 \pm 0.03^{\mathrm{aA}}$ & $7.90 \pm 0.30^{\mathrm{bA}}$ & $8.51 \pm 0.12^{\mathrm{aA}}$ & $8.41 \pm 0.18^{\mathrm{aA}}$ \\
\hline \multirow[t]{5}{*}{$\mathrm{AN}^{2}$} & 0 & $5.47 \pm 0.04^{\mathrm{aC}}$ & $5.47 \pm 0.04^{\mathrm{aC}}$ & $5.41 \pm 0.00^{\mathrm{aC}}$ & $5.41 \pm 0.00^{\mathrm{aC}}$ & $5.44 \pm 0.24^{\mathrm{aC}}$ & $5.44 \pm 0.24^{\mathrm{aC}}$ \\
\hline & 3 & $5.45 \pm 0.14^{\mathrm{abC}}$ & $5.62 \pm 0.21^{\mathrm{aC}}$ & $5.24 \pm 0.23^{\mathrm{bC}}$ & $5.56 \pm 0.24^{\mathrm{abC}}$ & $5.60 \pm 0.27^{\mathrm{aC}}$ & $5.60 \pm 0.24^{\mathrm{aC}}$ \\
\hline & 6 & $5.37 \pm 0.16^{\mathrm{abC}}$ & $5.76 \pm 0.20^{\mathrm{aC}}$ & $5.52 \pm 0.29^{\mathrm{abcC}}$ & $5.33 \pm 0.16^{\mathrm{cC}}$ & $5.61 \pm 0.13^{\mathrm{abcC}}$ & $5.69 \pm 0.21^{\mathrm{abC}}$ \\
\hline & 9 & $6.64 \pm 0.38^{\mathrm{bcB}}$ & $6.78 \pm 0.21^{\mathrm{abcB}}$ & $7.06 \pm 0.44^{\mathrm{abB}}$ & $6.41 \pm 0.44^{\mathrm{cB}}$ & $7.17 \pm 0.31^{\mathrm{aB}}$ & $6.89 \pm 0.36^{\mathrm{abcB}}$ \\
\hline & 12 & $8.50 \pm 0.09^{\mathrm{aA}}$ & $8.49 \pm 0.01^{\mathrm{aA}}$ & $8.38 \pm 0.27^{\mathrm{abA}}$ & $8.23 \pm 0.05^{\mathrm{bA}}$ & $8.56 \pm 0.07^{\mathrm{aA}}$ & $8.50 \pm 0.08^{\mathrm{aA}}$ \\
\hline
\end{tabular}

\footnotetext{
${ }^{a-c}$ Values (Means \pm SD) with different superscripts in the same row differ significantly $(\mathrm{p}<0.05)$.

${ }^{A-E}$ Values (Means \pm SD) with different superscripts in the same column differ significantly $(\mathrm{p}<0.05), \mathrm{n}=6$

${ }^{1}$ Aerobic bacteria. ${ }^{2}$ Anaerobic bacteria.
} 
ostrich but no fixed trend was found in redness.

With MAP treatments, a trend was found in CIE L* in which ttoekgalbi packed with $70 \% \mathrm{~N}_{2}$-MAP tends to be darker (lower CIE L*) than ttoekgalbi packed with $70 \% \mathrm{O}_{2^{-}}$ MAP from $3 \mathrm{~d}$ to $12 \mathrm{~d}$ of storage. Our earlier studies (Muhlisin et al., 2010) showed that CIE L* value in $70 \%$ $\mathrm{N}_{2}$-MAP was lower than in that $70 \% \mathrm{O}_{2}$-MAP in Hanwoo ground beef. In contrast, Suman et al. (2010) noticed that difference in gas composition did not affect the CIE $\mathrm{L}^{*}$. In redness (CIE a*), $\mathrm{N}_{2}$-MAP resulted in more red color compare to $70 \% \mathrm{O}_{2}$-MAP from 3 to $12 \mathrm{~d}$ of storage in all treatments. Control ttoekgalbi packed with $70 \% \mathrm{~N}_{2}$-MAP showed the highest CIE $a^{*}$ value among the treatments. The treatments with $70 \% \mathrm{~N}_{2}$-MAP seemed to be more effective in preserving the red color of toekgalbi compared to $70 \%$ $\mathrm{O}_{2}$-MAP.

Microbiology: No differences were found in the bacterial counts of both aerobic and anaerobic bacteria (Table 7). This result implied that fat replacement in low-fat ttoekgalbi had no effect on bacterial counts during storage. Muguerza et al. (2002) reported that fat level had no effects on lactic acid bacterial counts of low fat fermented sausages. Different gas composition in MAP did not affect the aerobic and anaerobic bacterial counts in control ttoekgalbi and low-fat ttoekgalbi with $100 \%$ fat replacement. The effects of $70 \% \mathrm{~N}_{2}$-MAP was observed on low-fat ttoekgalbi with $50 \%$ fat replacement, in which $\mathrm{N}_{2}$-MAP lowered the aerobic bacterial counts on 9 to $12 \mathrm{~d}$ storage, and anaerobic bacterial counts on 6 to $12 \mathrm{~d}$ of storage. Similar bacterial counts in $70 \% \mathrm{O}_{2}$-MAP and $70 \% \mathrm{~N}_{2}$-MAP may be due to the similar percentage of $\mathrm{CO}_{2}$ (both contained $30 \% \mathrm{CO}_{2}$ ). $\mathrm{CO}_{2}$ is utilized in MAP gas composition because of its antibacterial effects. In addition, Smith et al. (1990) suggested that $20-60 \%$ of $\mathrm{CO}_{2}$ in MAP is required to detain the growth of bacteria.

\section{ACKNOWLEDGEMENTS}

This research was supported by Technology Development Program for Agriculture and Forestry (108061-03-2-HD120), Ministry for Food, Agriculture, Forestry and Fisheries, Republic of Korea.

\section{REFERENCES}

Abiola, S. S. and S. W. Adegbaju. 2001. Effect of substituting pork backfat with rind on quality characteristics of pork sausage. Meat Sci. 58:409-412.

AOAC. 1995. Official methods of analysis. Association of Official Analytical Chemists, Washington DC, USA.

Arashihar, X., O. Hisar, M. Kaya and T. Yanik. 2004. Effects of modified atmosphere and vacuum packaging on microbiological and chemical properties of rainbow trout (Oncorynchus mykiss) fillets. Int. J. Food Microbiol. 97:209-
214.

Berry, B. W. and W. P. Wergin. 1993. Modified pregelatinized potato starch in low-fat ground beef patties. J. Muscle Foods 4:305-320

Blakistone, B. A. 1999. Meats and poultry. In: Principles and applications of modified atmosphere packaging of foods (Ed. B. A. Blakistone), Aspen Publisher, Maryland, pp. 240-290.

Cayuela, J. M., M. D. Gil, S. Banon and M. D. Garrido. 2004. Effect of vacuum and modified atmosphere packaging on the quality of pork loin. Eur. Food Res. Technol. 219:316-320.

Choi, Y. S., J. H. Choi, D. J. Han, H. Y. Kim, M. A. Lee and H. W. Kim. 2009. Characteristics of low-fat meat emulsion systems with pork fat replaced by vegetable oils and rice bran fiber. Meat Sci. 82:266-271.

Choi, Y. S., J. H. Choi, D. J. Han, H. Y. Kim, M. A. Lee, H. W. Kim, J. W. Lee, H. J. Chung and C. J. Kim. 2010. Optimization of replacing pork back fat with grape seed oil and rice bran fiber for reduced-fat meat emulsion systems. Meat Sci. 84:212218.

Garzon, G. A., F. K. McKeith, J. P. Gooding, F. C. Felker, D. E. Palmquist and M. S. Brewer. 2003. Characteristics of low-fat beef patties formulated with carbohydrate-lipid composite. Food Sci. 68:2050-2056.

Hoffman, L. C. and F. D. Mellet. 2003. Quality characteristics of low fat ostrich meat patties formulated with either pork lard or modified corn starch, soya isolate and water. Meat Sci. 65:869875.

Hong, G. P., S. Lee and S. G. Min. 2004. Effect of substituted level of added water for fat on the quality characteristics of spreadable liver sausage. Food Sci. Biotechnol. 13:397-402.

Hughes, E., A. M. Mullen and D. J. Troy. 1998. Effects of fat level, tapioca starch and whey protein in frankfurters formulated with 5\% and 12\% fat. Meat Sci. 48:169-180.

John, L., D. Cornforth, C. E. Carpenter, O. Sorheim, B. C. Pettee and D. R. Whittier. 2005. Color and thiobarbituric acid values of cooked top sirloin steaks packaged in modified atmospheres of $80 \%$ oxygen, or $0.4 \%$ carbon monoxide, or vacuum. Meat Sci. 69:441-449.

Khalil, A. H. 2000. Quality characteristics of low-fat beef patties formulated with modified corn starch and water. Food Chem. 68:61-68.

Kim, J. M. and C. M. Lee. 1987. Effect of starch on textural properties of surimi gel. J. Food Sci. 52:722-725.

Kohsaka, K. 1975. Freshness preservation of food and measurement. Food Ind. 18:105-111.

Lin, K. W. and S. H. Lin. 2002. Effects of sodium lactate and trisodium phosphate on the physicochemical properties and shelf-life of low-fat Chinese-style sausage. Meat Sci. 60:147154.

Lund, M. N., M. S. Hviid and L. H. Skibsted. 2007. The combined effect of antioxidants and modified atmosphere packaging on protein and lipid oxidation in beef patties during chill storage. Meat Sci. 76:226-233.

Luruena-Martinez, M. A., A. M. Vivar-Quintana and I. Revilla. 2004. Effect of locust bean/xanthan gum addition and replacement of pork fat with olive oil on the quality characteristics of low-fat frankfurters. Meat Sci. 68:383-389.

Mansour, E. H. and A. H. Khalil. 1997. Characteristics of low-fat beefburger as influenced by various types of wheat 
fibers. Food Res. Int. 30:199-205.

Martinez, L., D. Djenane, I. Cilla, J. A. Beltran and P. Roncales. 2005. Effect of different concentrations of carbon dioxide and low concentration of carbon monoxide on the shelf-life of fresh pork sausages packaged in modified atmosphere. Meat Sci. 71:563-570.

McMillin, K. W. 2008. Where is MAP Going? A review and future potential of modified atmosphere packaging for meat: review. Meat Sci. 80:43-65.

Muguerza, E., O. Gimeno, D. Ansorena, J. G. Bloukas and I. Astiasaran. 2001. Effect of replacing pork backfat with preemulsified olive oil on lipid fraction and sensory quality of Chorizo de Pamplona-a traditional Spanish fermented sausage. Meat Sci. 59:251-258.

Muhlisin, S. M. Kang, W. H. Choi, K. T. Lee, S. H. Cheong and S. K. Lee. 2010. Combined effects of modified atmosphere packaging on organic acid salts (sodium acetate and calcium lactate) on the quality and shelf-life of Hanwoo ground beef patties. Korean J. Food Sci. Anim. Resour. 30:658-694.

Nassos, P. S., A. D. King and A. E. Stafford. 1983. Relationships between lactic concentration and bacterial spoilage in ground beef. Appl. Environ. Microbiol. 46:894-900.

Osburn, W. N. and J. T. Keeton. 1994. Konjac four Gel as fat substitute in low-fat prerigor fresh pork sausage. J. Food Sci. 59:484-489.

Papadima, S. N. and J. G. Bloukas. 1999. Effect of fat level and storage conditions on quality characteristics of traditional Greek sausages. Meat Sci. 51:103-113.

Park, J. C., J. Y. Jeong, E. S. Lee, J. H. Choi, Y. S. Choi and L. H. Yu. 2005. Effects of replaced plant oils on the quality properties in low-fat hamburger patties. Korean J. Food Sci. Technol. 37:412-417.
Prabhu, G. A. and J. G. Sebranek. 1997. Quality characteristics of ham formulated with modified corn starch and kappacarrageenin. J. Food Sci. 62:198-202.

Ruiz-Capillas, C. and A. Monal. 2001. Correlation between biochemical and sensory quality indices in hake stored in ice. Food Res. Int. 34:441-447.

Sebranek, J. G. and T. A. Houser. 2006. Modified atmosphere packaging. In: advance technology for meat processing (Ed. L. M. L. Nollet and F. Toldra). Taylor \& Francis Group, Florida, pp. 419-447.

Sinhuber, R. O. and T. C. Yu. 1977. The 2-thiobarbituric acid reaction, an objective measure of the oxidative deterioration occurring in fat and oil. J. Jap. Soc. Fish Sci. 26:259-267.

Skibsted, L. H., A. Mikkelsen and G. Bertelsen. 1998. Lipidderived off-flavours in meat. In: flavor of meat, meat products and seafoods (Ed. F. Shahidi). Blackie Academic \& professional, London, pp. 217-248.

Smith, J. P., H. S. Ramaswamy and B. K. Simpson. 1990. Development in food packaging technology. Part II. Storage aspects. Trends Food Sci. Technol. 5:111-118.

Suman, S. P., R. A. Mancini, P. Joseph, R. Ramanathan, M. K. R. Konda, G. Dady, B. M. Naveena and I. López-López. 2010. Color-stabilizing effect of lactate on ground beef is packagingdependent. Meat Sci. 84:329-333.

Troutt, E. S., M. C. Hunt, D. E. Johnson, J. R. Claus, C. L. Kastner and D. H. Kropf. 1992. Characteristics of low-fat ground beef containing texture-modifying ingredients. J. Food Sci. 57:1924.

Viana, E. S., L. A. M. Gomide and M. C. D. Vanetti. 2005. Effect of modified atmospheres on microbiological, color and sensory properties of refrigerated pork. Meat Sci. 71:696-705. 